\title{
ZMIANA ZASAD ORGANIZACJI I FUNKCJONOWANIA ORGANÓW STANOWIACCYCH JEDNOSTEK SAMORZĄDU TERYTORIALNEGO - WZMACNIANIE CZY OSŁABIANIE DECENTRALIZACJI?
}

\section{Wprowadzenie}

Decentralizacja jest uznawana za jedną z zasad prawa administracyjnego $^{1}$. Ma ona charakter ustrojowy, natomiast jej merytoryczne wypełnienie stanowi zasada pomocniczości ${ }^{2}$ Zasada decentralizacji ma swoje umocowanie konstytucyjne. Zgodnie z postanowieniami Konstytucji RP ustrój terytorialny Rzeczypospolitej Polskiej zapewnia decentralizację władzy publicznej. Jak wskazuje P. Sarnecki: „Konstytucyjny wymóg «zapewnienia» decentralizacji władzy publicznej w ustroju terytorialnym kierowany jest w pierwszej kolejności do ustawodawcy, a stylizacja tego przepisu wskazuje, iż konstytucja nie przesądza o istnieniu, w momencie nabierania mocy prawnej, tego rodzaju ustroju

Rafał Budzisz - doktor nauk prawnych, Zakład Prawa Samorządu Terytorialnego Katedra Prawa Administracyjnego i Nauki Administracji, Uniwersytet Łódzki.

1 Por. E. Olejniczak-Szałowska, Zasada centralizacji i decentralizacji oraz koncentracji i dekoncentracji [w:] Prawo administracyjne. Pojęcia, instytucje, zasady w teorii i orzecznictwie, red. M. Stahl, Warszawa 2016, s. 183 i powołana tam literatura.

2 I. Niżnik-Dobosz, Zasady ustroju polskiej administracji publicznej [w:] Zasady w prawie administracyjnym. Teoria, praktyka, orzecznictwo, red. Z. Duniewska, M. Stahl, A. Krakała, Warszawa 2018, s. 148. 
terytorialnego"’3. Z kolei J. Korczak zauważa, że decentralizacja jest procesem, który przechodzi zarówno okresy wzmożenia, jak i osłabienia, prowadzące czasem wręcz do recentralizacji ${ }^{4}$. Wszelkie przejawy tego ostatniego zjawiska pozostawiają jednak wątpliwości natury konstytucyjnej, przewiduje ona bowiem decentralizację jako zasadę ustrojową ${ }^{5}$. Aktualne pozostają słowa J. Starościaka, który podnosił, że nie istnieją systemy administracji całkowicie scentralizowane lub zdecentralizowane. Można natomiast mówić o pewnych tendencjach rozwojowych systemu administracji, na które wpływa układ stosunków społecznych i ekonomicznych ${ }^{6}$. Dziś można by dodać również do katalogu tych determinantów czynnik polityczny, będący swoistą sumą dwóch poprzednich. Te trzy zmienne powodują, że pytanie o tendencje w kształtowaniu ustroju administracji pozostaje aktualne.

Zasada decentralizacji była też przedmiotem analizy Trybunału Konstytucyjnego, który w jednym ze swoich orzeczeń wskazał, że: „Pojęcie decentralizacji, do którego odwołuje się konstytucja jest pojęciem wielowymiarowym, obejmującym z jednej strony zakaz skupiania władzy, z drugiej zaś nakaz poszukiwania najbardziej efektywnych rozwiązań strukturalnych. Zasada decentralizacji powinna być rozumiana w harmonii z innymi zasadami ustrojowymi, a w szczególności z zasadą dobra wspólnego i efektywności działania samorządu, którego jednostki winny posiadać «zdolność wykonywania zadań publicznych»"7. Nie wystarczy zatem sam fakt przeniesienia uprawnień decyzyjnych do odrębnych organizacyjnie podmiotów o charakterze terenowym, ważne jest również to, czy efektywnie wykonują one powierzone zadania.

${ }^{3}$ Por. P. Sarnecki, Komentarz do art. 15 [w:] Konstytucja Rzeczypospolitej Polskiej: komentarz, red. L. Garlicki, M. Zubik, t. 1, Wstęp, art. 1-29, Warszawa 2016.

${ }^{4}$ J. Korczak, Konstytucyjne podstawy struktury i funkcji samorzadu terytorialnego [w:] System Prawa Administracyjnego, t. 2, Konstytucyjne podstawy funkcjonowania administracji publicznej, red. Z. Niewiadomski, A. Wróbel, Warszawa 2012, s. 195.

${ }_{5}^{5}$ Por. J. Korczak, Decentralizacja i recentralizacja $w$ administracji publicznej na przykładzie zadań własnych i zleconych jednostek samorzadu terytorialnego [w:] Aktualne problemy funkcjonowania samorzadu terytorialnego, red. E. Ura, E. Feret, S. Pieprzny, Sandomierz-Rzeszów 2017, s. 32-33.

${ }^{6}$ J. Starościak, Decentralizacja administracji, Warszawa 1960, s. 25.

7 Wyrok TK z 18.02.2003 r., K 24/02, OTK-A 2003/2, poz. 11. 
Najważniejszym przejawem decentralizacji jest samorząd terytorialny. Zapewnia udział społeczności lokalnych w sprawowaniu władzy lokalnej (bezpośrednio i pośrednio) oraz gwarantuje zaspokajanie zbiorowych potrzeb wspólnoty ${ }^{8}$. Analiza ustroju samorządu terytorialnego wiąże się z oceną jakości decentralizacji, jej efektywności, a przez to trwałości. Jeżeli bowiem to ustawodawca ma określać zakres decentralizacji i może w tym zakresie dokonywać zmian, powinien wykazać w przypadku podjęcia działań centralizacyjnych, że rozwiązania decentralizacyjne nie przyniosły oczekiwanych efektów. $\mathrm{Z}$ tej perspektywy zasadne jest badanie zmian ustroju samorządu terytorialnego pod kątem wzmacniania mechanizmów decentralizacji. Przyczynkiem do takich badań w sposób naturalny stają się kolejne nowelizacje prawa samorządowego. Ustawą z 11.01.2018 r. o zmianie niektórych ustaw w celu zwiększenia udziału obywateli w procesie wybierania, funkcjonowania i kontrolowania niektórych organów publicznych ${ }^{9}$ dokonano między innymi zmian dotyczących zasad organizacji i funkcjonowania organów stanowiących wszystkich jednostek samorządu terytorialnego ${ }^{10}$.

\section{Wydłużenie kadencji rady}

Po pierwsze, wspomnianą nowelizacją dokonano wydłużenia kadencji rady (sejmiku) z 4 do 5 lat. $Z$ kadencją rady gminy powiązano również kadencję wójta, burmistrza, prezydenta miasta, dokonując również jej wydłużenia. Zmiana ta niesie ze sobą wiele pozytywnych skutków, takich chociażby jak umożliwienie realizacji programów wyborczych, których wykonanie we właściwie trzyletnim okresie (budżet na pierwszy rok kadencji uchwalała z reguły poprzednia

${ }^{8}$ Por. szerzej E. Olejniczak-Szałowska, Pojęcie $i$ cechy samorządu terytorialnego [w:] Prawo..., red. M. Stahl, s. 368 i n.

${ }^{9}$ Ustawa z 11.01.2018 r. o zmianie niektórych ustaw w celu zwiększenia udziału obywateli w procesie wybierania, funkcjonowania i kontrolowania niektórych organów publicznych (Dz.U. poz. 130) - dalej jako: nowelizacja styczniowa/ustawa nowelizująca.

${ }^{10}$ Przepisy nowelizacji styczniowej stosuje się do kadencji organów jednostek samorządu terytorialnego następujących po kadencji, w czasie której ustawa o zmianie niektórych ustaw w celu zwiększenia udziału obywateli w procesie wybierania, funkcjonowania i kontrolowania niektórych organów publicznych weszła w życie. 
rada, w związku z jesiennym terminem wyborów). Zwiększa tė̇ pewną stabilizację polityczną w jednostkach samorządowych. Wydłużenie kadencji może pozytywnie wpłynąć na efektywność wykonywania zadań przez organy samorządowe i tym samym wzmocnić tę zdecentralizowaną formę administracji. Natomiast w sytuacji braku skuteczności w ich wykonywaniu pozostają do zastosowania instrumenty nadzoru lub możliwość odwołania przez mieszkańców organów samorządowych (tych pochodzących z wyborów bezpośrednich) w drodze referendum lokalnego. Ponadto wydłużenie kadencji powoduje mniejszą częstotliwość wyborów, co niewątpliwie obniża koszty ich organizowania. Jednocześnie wprowadzono również ograniczenie biernego prawa wyborczego przy kandydowaniu do organu wykonawczego gminy, wskazując, że nie ma prawa wybieralności w danej gminie osoba, która została uprzednio dwukrotnie wybrana na wójta, burmistrza, prezydenta miasta w tej gminie w wyborach tego organu zarządzonych na podstawie art. $474 \$ 1$ Kodeksu wyborczego ${ }^{11}$.

Zmiana czasu trwania kadencji wymusiła również ograniczenie przeprowadzania nowych wyborów - od dnia wejścia w życie niniejszej ustawy do zakończenia kadencji organów jednostek samorządu terytorialnego, w czasie której niniejsza ustawa weszła w życie, nie przeprowadza się nowych, przedterminowych i uzupełniających wyborów tych organów, z wyjątkiem wyborów zarządzonych przed dniem wejścia w życie niniejszej ustawy.

\section{Komisja skarg, wniosków i petycji}

Istotną rolę w merytorycznej sferze pracy organu stanowiącego odgrywają jego komisje. W obecnym układzie organizacyjnym komisja rewizyjna jest jedyną obligatoryjną komisją rady (sejmiku) ${ }^{12}$. W wy-

11 Ustawa z 5.01.2011 r. - Kodeks wyborczy (Dz.U. z 2018 r. poz. 754 ze zm.) - dalej jako: Kodeks wyborczy.

${ }_{12}$ Por. B. Jaworska-Dębska, Komisje rady gminy, rady powiatu oraz sejmiku województwa [w:] Prawo..., red. M. Stahl, s. 390. 
niku nowelizacji styczniowej ustawodawca wprowadził do struktury rady (sejmiku) nową obligatoryjną komisję - komisję skarg, wniosków i petycji. Pojawienie się tego nowego ciała zostało powiązane ze wskazaniem w ustawach ustrojowych, że organ stanowiący rozpatruje skargi na działania organów wykonawczych i samorządowych jednostek organizacyjnych. Właśnie do ich rozpatrywania powołano nową komisję. W ustawach o samorządzie gminnym, o samorządzie powiatowym i o samorządzie województwa wprowadzono również regulację przewidującą, że organ stanowiący rozpatruje wnioski oraz petycje składane przez obywateli ${ }^{13}$. Także i ten zakres spraw powierzono komisji skarg, wniosków i petycji. Ustawowo określono ponadto skład tej komisji, na wzór komisji rewizyjnej, wskazując, że do jej grona mają wchodzić radni, w tym przedstawiciele wszystkich klubów. Członkami komisji skarg, wniosków i petycji nie mogą być natomiast radni pełniący funkcje przewodniczącego i zastępcy przewodniczącego rady (sejmiku) ${ }^{14}$. Wprowadzenie do ustroju organu stanowiącego nowej komisji wymaga również zmiany statutu i określenia w nim zasad i trybu jej działania. Zmiana w strukturze wewnętrznej rady (sejmiku) oznacza także konieczność przegrupowania zadań wykonywanych przez inne komisje. Dotychczas powszechną praktyką było powierzanie rozpatrywania skarg i wniosków komisji rewizyjnej lub też komisji merytorycznie właściwej. Zwłaszcza to drugie rozwiązanie dawało szanse na rozpatrywanie skarg przez gremium o możliwie najlepszym merytorycznym przygotowaniu. Nowe rozwiązanie wymagać będzie od rady, ale też od klubów, dużego wyczucia w obsadzie personalnej nowej komisji, aby umożliwić jej prawidłowe działanie.

${ }^{13}$ Dotychczas w ustawie z 11.07.2014 r. o petycjach (Dz.U. z 2018 r. poz. 870) ustawodawca przewidywał, że organ stanowiący może wskazać komisję do ich rozpatrywania. Obecnie w związku z nowelizacją ustawy o petycjach przez nowelizację styczniową możliwość taka została wyłączona.

${ }_{14}$ Pozwala to na stwierdzenie, że uwagi przedstawicieli doktryny dotyczące składu komisji rewizyjnej można uznać za aktualne również w odniesieniu do komisji skarg, wniosków i petycji. Por. C. Martysz, Komentarz do art. 18(a) [w:] Ustawa o samorządzie gminnym. Komentarz, red. B. Dolnicki, Warszawa 2016. 


\section{Transmitowanie i utrwalanie obrad rady (sejmiku)}

W nowej kadencji obrady organów stanowiących będą obligatoryjnie transmitowane za pomocą urządzeń rejestrujących obraz i dźwięk. O ile sama idea szerszego upubliczniania przebiegu sesji rady (sejmiku) zasługuje na poparcie, o tyle enigmatyczna treść nowelizacji w tym zakresie może budzić wiele wątpliwości. Po pierwsze, czy transmisja ma być przekazem „na żywo” czy też umożliwiać późniejsze odtworzenie. Obok transmitowania ustawodawca wprowadził bowiem obowiązek utrwalania obrad i udostępniania ich w Biuletynie Informacji Publicznej i na stronie internetowej jednostki samorządowej oraz w inny sposób zwyczajowo przyjęty, co sugerowałoby przekaz obrad w czasie rzeczywistym. Po drugie, gdzie transmisja ma być kierowana? Mogą to być np. lokalne media, ale w małych jednostkach nie ma takich możliwości. Czy ma to zatem być transmisja on-line w Internecie, czy też wystarczy ustawienie ekranu na korytarzu w urzędzie? Pytania te nie znajdują odpowiedzi w treści ustawy ${ }^{15}$. Środowiska samorządowe wyrażają obawy, że poszczególni radni będą wykorzystywać transmisje do promowania własnej osoby oraz podejmowania spektakularnych działań mających na celu wzbudzenie zainteresowania i wykazania się pseudoaktywnością. Niepokój przy transmisji „na żywo” rodzą również ograniczone możliwości zagwarantowania ochrony danych osobowych ${ }^{16}$. Obecnie ujawnienie danych

15 Również uzasadnienie projektu ustawy zawiera jedynie zreferowanie treści przepisów, natomiast w najmniejszym stopniu nie ujawnia powodów wprowadzanej zmiany. Jak czytamy w nim: „Obrady odpowiednio rady gminy, powiatu, sejmiku województwa będą zgodnie $\mathrm{z}$ intencją projektem transmitowane i utrwalane za pomocą urządzeń rejestrujących obraz i dźwięk. Nagrania obrad będą udostępniane na stronach internetowych jednostek samorządów terytorialnych oraz w inny sposób zwyczajowo przyjęty. Proponuje się aby do transmisji i utrwalania obrad organów stanowiących jednostek samorządu terytorialnego mogły być wykorzystywane urządzenia służące do transmisji lub rejestracji czynności obwodowej komisji wyborczej, o których mowa w ustawie z 5 stycznia 2011 r. Kodeks wyborczy".

16 Obowiązek taki wynikał już z ustawy z 29.08.1997 r. o ochronie danych osobowych (Dz.U. z 2016 r. poz. 922 ze zm.), zgodnie z którą każdy ma prawo do ochrony dotyczących go danych osobowych, natomiast przetwarzanie danych osobowych może mieć miejsce ze względu na dobro publiczne, dobro osoby, której dane dotyczą, lub dobro osób trzecich w zakresie i trybie określonym ustawą. Por. też M. Lewicki, Opinia prawna w sprawie 78/DOR/2013, administracja.mswia.gov.pl/download/58/12548/78DOR.doc 
osobowych w czasie sesji mogło być skorygowane poprzez proces anonimizacji protokołu z obrad rady (sejmiku) przed jego udostępnieniem. Bezpośrednie transmitowanie obrad w istocie uniemożliwia podjęcie takiego działania.

Ustawodawca nie precyzuje również parametrów nagrania czy też transmisji. Czy użycie kamery o bardzo niskiej rozdzielczości i słabej jakości dźwięku zapewni dostateczny efekt szerszego upubliczniania przebiegu sesji rady (sejmiku)? Można mieć co do tego wątpliwości. Próbą obniżenia kosztów wprowadzonych zmian związanych z transmitowaniem i utrwalaniem obrad rady (sejmiku) jest ustawowe zagwarantowanie możliwości wykorzystania do tych celów urządzeń służących do transmisji lub rejestracji czynności obwodowej komisji wyborczej, o których mowa w Kodeksie wyborczym. Wymaga to zawarcia przez radę gminy, radę powiatu oraz sejmik województwa porozumienia z Szefem Krajowego Biura Wyborczego. Porozumienie to ma sprecyzować zasady korzystania $\mathrm{z}$ wymienionych urządzeń. Przepisy nie przewidują wprost sankcji związanych z brakiem transmisji. Pojawia się jednak pytanie o możliwość stwierdzenia nieważności uchwał podjętych na sesji z naruszeniem zasad transmisji. Transmisja dotyczy wyłącznie obrad rady i nie obowiązuje w odniesieniu do posiedzeń komisji rady.

Bez wątpienia zwiększanie jawności działania oraz dostępu do posiedzeń organów stanowiących samorządu stanowi instrument zwiększania świadomości mieszkańców w zakresie mechanizmów i efektywności działania organów samorządowych oraz wzmaga instrument kontroli społecznej sprawowanej przez mieszkańców jednostki samorządowej ${ }^{17}$. Z tej perspektywy omawiana zmiana wzmacnia proobywatelski trend w działalności samorządu terytorialnego i tę formę administracji zdecentralizowanej.

(dostęp: 26.10.2018 r.). Obecnie ochronę danych osobowych gwarantują przepisy rozporządzenia Parlamentu Europejskiego i Rady (UE) 2016/679 z 27.04.2016 r. w sprawie ochrony osób fizycznych w związku z przetwarzaniem danych osobowych i w sprawie swobodnego przepływu takich danych oraz uchylenia dyrektywy 95/46/WE (ogólne rozporządzenie o ochronie danych) (Dz.Urz. UE L z 2016 r., s. 1, ze zm.).

${ }_{17}$ Por. B. Jaworska-Dębska, Kontrola społeczna [w:] Prawo administracyjne..., red. M. Stahl, s. 559. 


\section{Forma głosowania}

Ustawodawca od nowej kadencji rad (sejmiku) dokonał zmiany trybu jawnych głosowań. Jawność głosowania jest regułą, od której możliwe są wyłącznie określone ustawowo odstępstwa ${ }^{18}$. Dotyczą one np. wyboru przewodniczącego czy też zastępców przewodniczącego rady (sejmiku). Przepisy ustawy nowelizującej wprowadziły natomiast nową kategorię trybu głosowania (oprócz już istniejącego trybu jawnego, tajnego i imiennego). W kolejnej kadencji głosowania jawne na sesjach rady odbywać się będą za pomocą urządzeń umożliwiających sporządzenie i utrwalenie imiennego wykazu głosowań radnych. W istocie uznać trzeba, że jest to tryb głosowania jawnego zbliżony do głosowania imiennego, przy czym realizowany za pomocą urządzeń elektronicznych. Ta forma głosowania umożliwia bowiem ustalenie tego, jak głosowali poszczególni radni. Podkreślić trzeba, że wprowadzany tryb głosowań ma charakter obligatoryjny w odniesieniu do głosowań jawnych z jednym ustawowym wyjątkiem. Ustawodawca przewidział bowiem sytuację, w której z przyczyn technicznych nie jest możliwe głosowanie za pomocą urządzeń elektronicznych.

18 Zgodnie z art. 14 u.s.g. uchwały rady gminy zapadają zwykłą większością głosów w obecności co najmniej połowy ustawowego składu rady, w głosowaniu jawnym, chyba że ustawa stanowi inaczej. Analogiczne rozwiązanie zawiera art. 13 u.s.p. oraz 19 u.s.w., przy czym ten ostatni wyraźnie wskazuje na możliwość wprowadzenia głosowania imiennego jako reguły. Odstępstw takich nie mogą wprowadzać statuty jednostek samorządowych (por. wyrok WSA w Olsztynie z 29.08.2017 r., II SA/Ol 531/17, LEX nr 2354806, w którym sąd stwierdził: „Skoro ustawodawca w sposób jednoznaczny uregulował w u.s.g. tryb głosowania i przypadki, w których głosowanie może być przeprowadzone imiennie, to należy uznać, że rada gminy nie jest upoważniona do wprowadzenia w statucie gminy generalnej reguły głosowania jawnego imiennego"). Wyraźnego podkreślenia wymaga także fakt, że poza głosowaniem jawnym i tajnym na gruncie przepisów u.s.g. występuje także głosowanie jawne imienne. Ten tryb głosowania nie występuje w przepisach u.s.p., natomiast jest znany w u.s.w. Głosowanie jawne imienne stanowi kwalifikowaną formę zwykłego głosowania jawnego. Podstawową różnicą pomiędzy tymi dwoma trybami głosowania jest to, że wyniki głosowania jawnego imiennego zostają udokumentowane w protokole sesji poprzez odnotowanie imienia i nazwiska każdego radnego oraz sposobu, w jaki głosował, tj. czy był za przyjęciem uchwały, czy przeciw, czy też wstrzymał się od głosowania. Przy zwykłym głosowaniu jawnym w protokole sesji odnotowuje się jedynie łączną liczbę głosów oddanych „za”, „przeciw” oraz „wstrzymujących się” przy podjęciu uchwały. Por. A. Wierzbica, Komentarz do art. 14 [w:] Ustawa..., red. B. Dolnicki. 
W takim przypadku przeprowadza się głosowanie imienne. To również potwierdza, że ustawodawca nie stawia znaku równości pomiędzy trybem głosowania imiennego a głosowaniem z wykorzystaniem aparatury do liczenia głosów.

Omawiana zmiana wymusza konieczność zakupu urządzeń technicznych zapewniających możliwość sporządzenia i utrwalenia imiennego wykazu głosowań radnych, co rodzi dodatkowe koszty funkcjonowania organu stanowiącego.

Wprowadzenie takiego trybu głosowania nie miałoby sensu, gdyby jego wynik nie był udostępniany mieszkańcom czy też szerzej wszystkim zainteresowanym sposobem głosowania poszczególnych radnych. Pewne wątpliwości może wzbudzać natomiast konieczność stosowania trzech form udostępniania wyników głosowań. Zgodnie z nowelizacją imienne wykazy głosowań radnych podaje się niezwłocznie do publicznej wiadomości w Biuletynie Informacji Publicznej i na stronie internetowej gminy oraz w inny sposób zwyczajowo przyjęty na obszarze jednostki samorządowej.

Zapewnienie społecznościom lokalnym uzyskania wiedzy na temat sposobu głosowania przez poszczególnych radnych w konkretnej sprawie również stanowi element wzmacniający instrumenty kontroli społecznej nad organami samorządowymi. Umożliwia ocenę sposobu głosowania przez poszczególnych radnych i konfrontowania go z przedstawianym programem wyborczym i składanymi w trakcie kampanii obietnicami.

\section{Kluby radnych}

Nowelizacja styczniowa wprowadziła również modyfikacje dotyczące klubu radnych. Trafnie na istotę klubu radnych wskazał Naczelny Sąd Administracyjny w orzeczeniu z 12.05.2017 r., zgodnie z którym: „Kluby radnych działające na zasadach określonych w statucie powinny być instrumentami pomagającymi radnemu kierować się dobrem wspólnoty samorządowej gminy, a także powinny pomagać 
w utrzymywaniu stałej więzi z mieszkańcami oraz ich organizacjami, a w szczególności w przyjmowaniu zgłaszanych przez mieszkańców gminy postulatów i przedstawianiu ich organom gminy do rozpatrzenia”. W tym samym orzeczeniu Sąd podkreślił również dobrowolny charakter zrzeszania się radnych, przy jednoczesnej konieczności zagwarantowania w statucie takiej możliwości. Sąd dodał: „Uchwalany przez radę gminy statut nie powinien ograniczać radnych w wykorzystywaniu przez nich wolności do zrzeszania się do tworzenia klubu radnych i pośrednio do wykonywania swoich zadań i obowiązków i uprawnień w przestrzeni zrzeszenia lub z wykorzystaniem instytucji zrzeszenia, jakim jest klub radnych"19. Orzeczenie to stanowiło odpowiedź na problem statutowego podwyższania liczby radnych mogących tworzyć kluby. W tym duchu należy również analizować w nowelizacji styczniowej określenie minimalnej liczby radnych mogących stworzyć klub. Zgodnie z nową regulacją wystarczy grupa trzech radnych do założenia klubu. Ocena tego rozwiązania nie może być jednak jednolita, w obecnie obowiązujących statutach znajdują się bowiem rozwiązania umożliwiające zrzeszanie się w kluby przez co najmniej dwóch radnych ${ }^{20}$. W tej sytuacji ustawowo ograniczono możliwość tworzenia klubu.

Oprócz dotychczasowej kompetencji klubu radnych do zgłaszania swojego kandydata do komisji rewizyjnej klubom radnych zagwarantowano również prawo wpływania na kształt porządku obrad organu stanowiącego. Przewodniczący rady (sejmiku) został bowiem zobowiązany do wprowadzenia do porządku obrad najbliższej sesji projektu uchwały zgłoszonego przez klub radnych. Wniosek w tej sprawie musi wpłynąć do rady (sejmiku) co najmniej 7 dni przed dniem rozpoczęcia sesji rady. Ustawodawca wprowadził jednak limit zgłaszania w tym trybie projektów uchwał do jednego na każdą kolejną sesję organu stanowiącego. W województwie samorządowym

19 Wyrok NSA w Warszawie z 12.05.2017 r., II OSK 2216/15, LEX nr 2321536.

${ }^{20}$ Por. przykładowo $\$ 18$ ust. 3 Statutu Miasta Pabianic, uchwała nr L/664/13 Rady Miejskiej Pabianice z 18.12.2013 r. w sprawie ogłoszenia tekstu jednolitego uchwały Nr XVIII/191/11 Rady Miejskiej w Pabianicach z 28.11.2011 r. w sprawie uchwalenia Statutu Miasta Pabianic, http://nowy-bip.um.pabianice.pl/uchwala/4641/uchwalanr-1-644-13 (dostęp: 26.10.2018 r.). 
nowelizacja styczniowa przyznała jeszcze jedno uprawnienie dla klubów radnych, ponieważ przewodniczącym komisji rewizyjnej będzie radny największego klubu radnych, który złożył oświadczenie o odmowie udzielenia poparcia zarządowi województwa - czyli klubu opozycyjnego. W sytuacji, w której dwa lub więcej klubów radnych składają się z równej liczby radnych, przewodniczącym może zostać radny każdego z takich klubów.

Wprowadzanie do ustawy kolejnych uściślających norm związanych z organizacją działania organów samorządowych zawęża chronioną konstytucyjnie samodzielność jednostki samorządowej w zakresie kształtowania struktury organizacyjnej swoich organów (art. 169 ust. 4 Konstytucji RP). W kontekście zasady decentralizacji uznać trzeba, że ograniczanie samorządu terytorialnego w możliwości samodzielnego określania zagadnień ustrojowych odnoszących się do organu stanowiącego osłabia instytucję samorządu.

\section{Raport o stanie jednostki samorządowej i wotum zaufania}

Organy stanowiące uzyskały w związku z omawianą nowelizacją jeszcze jeden istotny instrument sprawowania swojej funkcji kontrolnej w postaci rozpatrywania raportu o stanie jednostki samorządowej oraz podejmowania uchwały w sprawie udzielenia lub nieudzielenia wotum zaufania organowi wykonawczemu. Do tej pory wykorzystywano w tym celu instrument absolutorium. Słusznie jednak podkreślano w doktrynie i orzecznictwie, że absolutorium służy ocenie realizacji budżetu, nie zaś kompleksowej ocenie działalności organu wykonawczego ${ }^{21}$. Instytucja wotum zaufania została wprowadzona obok procedury absolutoryjnej. Kalendarium procedury przewiduje, że organ wykonawczy co roku do 31 maja przedstawia na sesji organu stanowiącego raport o stanie jednostki samorządowej. Raport zawiera informacje o działalności organu wykonawczego w roku poprzednim, w tym o realizacji polityk, programów i strategii, jak również uchwał

\footnotetext{
${ }^{21}$ C. Martysz, Komentarz do art. 28(a) [w:] Ustawa..., red. B. Dolnicki.
} 
organu stanowiącego i budżetu obywatelskiego. Rada (sejmik) może sprecyzować w drodze uchwały szczegółowe wymogi dotyczące raportu. Rozpatrzenie raportu następuje w drodze debaty podczas sesji, na której organ stanowiący rozstrzyga następnie o absolutorium. W debacie oprócz radnych mogą zabierać głos mieszkańcy jednostki samorządowej, którzy zgłoszą na piśmie zamiar udziału w debacie. Zgłoszenie musi być poparte określoną ustawowo liczbą podpisów. Ustawowy limit uczestników debaty spoza rady (sejmiku) wynosi 15 mieszkańców, lecz organ stanowiący może zwiększyć ten limit. Efektem przedstawienia raportu i debaty nad nim jest głosowanie rady (sejmiku) nad udzieleniem organowi wykonawczemu wotum zaufania. Uchwała w tej sprawie zapada bezwzględną większością głosów ustawowego składu rady (sejmiku). Niepodjęcie uchwały o udzieleniu wotum zaufania jest równoznaczne z podjęciem uchwały o jego nieudzieleniu. Ustawodawca zróżnicował skutki nieudzielenia wotum zaufania w gminie oraz w powiecie i województwie samorządowym. W gminie nieudzielenie wójtowi, burmistrzowi, prezydentowi miasta wotum zaufania w dwóch kolejnych latach daje radzie gminy możliwość podjęcia uchwały o przeprowadzeniu referendum w sprawie odwołania organu wykonawczego. Natomiast w dwóch pozostałych kategoriach jednostek samorządowych nieudzielenie wotum zaufania jest równoznaczne ze złożeniem wniosku o odwołanie zarządu. Organ stanowiący rozstrzyga w tej sprawie na sesji zwołanej nie wcześniej niż po upływie 14 dni od podjęcia uchwały w sprawie nieudzielenia zarządowi wotum zaufania. Odwołanie organu wykonawczego może nastąpić większością co najmniej 3/5 głosów ustawowego składu rady powiatu (sejmiku województwa), w głosowaniu jawnym.

Omawiana instytucja raportu o stanie jednostki samorządowej powiązana $z$ procedurą udzielania wotum zaufania organowi wykonawczemu zasługuje na pozytywną ocenę z kilku powodów. Po pierwsze, raport stanowi okazję do kompleksowego przedstawienia sytuacji jednostki samorządowej na forum publicznym i w zakresie wskazanym przez organ stanowiący. Po drugie, debata nad raportem daje szanse jej przeanalizowania i wyciągnięcia wniosków w zakresie ewentualnych nieprawidłowości. Po trzecie, w debacie mogą zabrać głos mieszkańcy jednostki samorządowej. Po czwarte, instytucja 
wotum zaufania stanowi formę oceny organu wykonawczego przez radę (sejmik) z możliwością podjęcia dalszych kroków w przypadku odmowy udzielenia wotum zaufania, co wzmacnia pozycję organu stanowiącego. W kontekście wzmacniania instrumentów zdecentralizowanej formy administracji, jaką jest samorząd terytorialny, omawiana zmiana wpisuje się w ten trend.

\section{Podsumowanie}

Instytucja samorządu terytorialnego jako podstawowa forma decentralizacji państwa wymaga systematycznej oceny i doskonalenia. Jednostki samorządowe powinny w coraz większym zakresie pogłębiać swój partycypacyjny charakter poprzez zwiększanie udziału obywateli w ich działalności ${ }^{22}$. Może odbywać się to również na gruncie ustrojowym, poprzez zwiększanie roli obywateli w sprawowaniu władzy na terenie jednostki samorządowej. Analizowana nowelizacja ustaw samorządowych wzmacnia również pozycję organu stanowiącego jako ciała przedstawicielskiego. Wzmocniona zostaje też pozycja mieszkańców jednostki samorządowej poprzez przyznanie im dodatkowych uprawnień (np. udziału w debacie nad raportem o stanie jednostki samorządowej czy też przyznanie ustawowego prawa do inicjatywy uchwałodawczej). W sferze zmiany zasad organizacji i funkcjonowania rad (sejmików) znacząco poprawia się także realizacja zasady jawności ich funkcjonowania poprzez transmitowanie obrad czy imienne wykazy głosowań radnych. Na zaznaczeniu zyskują również uprawnienia radnych ${ }^{23}$ oraz ich klubów. W tym zakresie zmiana zasad organizacji i funkcjonowania organów stanowiących jednostek samorządu terytorialnego wzmacnia samorząd jako zdecentralizowaną formę administracji publicznej. Jednak decentralizacja administracji zakłada pewną dozę samodzielności w działaniu organów zdecentralizowanych, również w sferze ustrojowej (art. 169 ust. 4 Konstytu-

${ }^{22}$ Ze względu na ograniczone ramy niniejszego opracowania oraz jego temat nie omówiono w nim ustawowej regulacji budżetu obywatelskiego, jak również inicjatywy obywatelskiej, wprowadzonych nowelą styczniową.

${ }^{23}$ Nowelizacja styczniowa przyznała radnym ustawowo uregulowane prawo do interpelacji i zapytań, jak również indywidualne uprawnienia kontrolne. 
cji RP). Kolejne szczegółowe regulacje ograniczają tę samodzielność, zakreślając coraz mniejsze pole do wewnętrznej regulacji ustroju jednostki samorządowej przez jej organy stanowiące. Coraz szerszy zakres ingerencji Państwa w tym zakresie może budzić uzasadnione obawy. O ile w części poszerzającej uprawnienia organu stanowiącego kierunek analizowanych zmian można uznać za prawidłowy, o tyle jakość regulacji prawnej nowelizacji styczniowej w omawianym zakresie może nasuwać wiele wątpliwości.

\section{Bibliografia:}

Jaworska-Dębska B., Komisje rady gminy, rady powiatu oraz sejmiku województwa [w:] Prawo administracyjne. Pojęcia, instytucje, zasady w teorii i orzecznictwie, red. M. Stahl, Warszawa 2016

Jaworska-Dębska B., Kontrola społeczna [w:] Prawo administracyjne. Pojęcia, instytucje, zasady w teorii i orzecznictwie, red. M. Stahl, Warszawa 2016

Korczak J., Decentralizacja i recentralizacja w administracji publicznej na przykładzie zadań własnych i zleconych jednostek samorzadu terytorialnego [w:] Aktualne problemy funkcjonowania samorzadu terytorialnego, red. E. Ura, E. Feret, S. Pieprzny, Sandomierz-Rzeszów 2017

Korczak J., Konstytucyjne podstawy struktury i funkcji samorzadu terytorialnego [w:] System Prawa Administracyjnego, t. 2, Konstytucyjne podstawy funkcjonowania administracji publicznej, red. Z. Niewiadomski, A. Wróbel, Warszawa 2012

Martysz C., Komentarz do art. 18(a) [w:] Ustawa o samorzadzie gminnym. Komentarz, red. B. Dolnicki, Warszawa 2016

Martysz C., Komentarz do art. 28(a) [w:] Ustawa o samorzadzie gminnym. Komentarz, red. B. Dolnicki, Warszawa 2016

Niżnik-Dobosz I., Zasady ustroju polskiej administracji publicznej [w:] Zasady $w$ prawie administracyjnym. Teoria, praktyka, orzecznictwo, red. Z. Duniewska, M. Stahl, A. Krakała, Warszawa 2018

Olejniczak-Szałowska E., Pojęcie i cechy samorzadu terytorialnego [w:] Prawo administracyjne. Pojęcia, instytucje, zasady w teorii i orzecznictwie, red. M. Stahl, Warszawa 2016 
Olejniczak-Szałowska E., Zasada centralizacji i decentralizacji oraz koncentracji i dekoncentracji [w:] Prawo administracyjne. Pojęcia, instytucje, zasady w teorii i orzecznictwie, red. M. Stahl, Warszawa 2016

Sarnecki P., Komentarz do art. 15 [w:] Konstytucja Rzeczypospolitej Polskiej: komentarz, t. 1, Wstęp, art. 1-29, red. L. Garlicki, M. Zubik, Warszawa 2016

Starościak J., Decentralizacja administracji, Warszawa 1960

Wierzbica A., Komentarz do art. 14 [w:] Ustawa o samorzadzie gminnym. Komentarz, red. B. Dolnicki, Warszawa 2016 